\title{
CONSERVATION POLICY OF LIVING NATURAL RESOURCES AND THEIR ECOSYSTEMS: A STUDY OF THE IMPLEMENTATION OF REGIONAL REGULATION OF MALINAU REGENCY NUMBER 4 OF 2007 CONCERNING MALINAU REGENCY AS A CONSERVATION REGENCY
}

\author{
Damus H.*, Doctoral Student \\ Environmental Science Program, Postgraduate School, University of Brawijaya, Indonesia
}

Hakim A., Hakim L., Endah S.

Department of Public Administrative Science, Faculty of Administrative Science, University of Brawijaya \& Department of Biology, Faculty of Science, University of Brawijaya, Indonesia

\section{*E-mail: damushendris@yahoo.com}

\begin{abstract}
In accordance with Law Number 47 of 1999 concerning The Establishment of Nunukan Regency, Malinau Regency, West Kutai Regency, East Kutai Regency and Bontang City, the area of Malinau regency is approximately $42,620.70 \mathrm{~km}^{2}$, where $90 \%$ of them is forest cover. This number shows that Malinau regency has a vast area of forest cover which also being the largest in Indonesia. In order to safeguard and protect the preservation of vast areas of virgin forest as well as its diverse and unique biodiversity so that it can fulfill its purposes as the absorber of carbon dioxide (C02) emissions and producer of oxygen (O2), the Malinau regency government immediately issued Regional Regulation Number 4 concerning Malinau Regency as a Conservation Regency with a limited definition that "a Regency area which as a whole is declared as conservation area, where natural resources that are not renewable are wisely managed to guarantee their utilization, and renewable natural resources are wisely managed to ensure the sustainability of their supply by preserving and improving the quality of its diversity". In addition to the biodiversity (genetics, species, and ecosystems) and diverse fauna species, this region stores various types of mines and minerals while also serve as the main stream and catchment area of major rivers in provinces of East Kalimantan and North Kalimantan. Regional Regulation Number 4 of 2007 states that those included in the conservation area consist of protected forest, tana Ulen/Adat, Kayan Mentarang National Park, forest cultivation area, non-forest cultivation area, and other utilization areas.
\end{abstract}

\section{KEY WORDS}

Biodiversity, conservation, lungs of the world, Malinau regency, state assets.

Based on Law as of 1990 concerning Conservation of the Living Natural Resources and Their Ecosystems, conservation of living natural resources is the management of living natural resources in which the utilization is carried out wisely to ensure the sustainability of its supply by preserving and improving the quality of its diversity. Furthermore, Law Number 18 of 2013 concerning The Prevention and Eradication of Forest Destruction in article 6 paragraph $\mathrm{c}$ also indicates that there are incentives for parties who contribute in preserving the forest.

The focus of this research is on the implementation of Regional Regulation of Malinau Regency Number 4 of 2007 concerning Malinau Regency as Conservation Regency. According to this regulation, conservation regency is a regency that being declared as a whole as a conservation where its non-renewable natural resources are wisely managed to guarantee its utilization, and where the utilization of renewable natural resources is wisely managed while also improving the quality of their diversity. Theoretically, this research related to public administration, especially policy implementation. 
Experts consider the policy implementation phase of a great importance since public policy, in principle, is preceded by policy implementation. Edwards III (1984) states that without effective implementation, the decision of policymakers will not be carried out successfully. Furthermore, Nugroho (2014) also argued that the measure of success and failure determined by formulation, implementation, and policy control, with the weight of $20 \%$, $60 \%$, and $20 \%$, respectively. Therefore, it can be seen that policy implementation requires activities or actions taken in order to carried out the contents of the policy with the aim of achieving policy objectives and occurs after policy formulation.

Nugroho (2014:214) also states that the implementation of policy often involves many policy actors, thus causing the execution of policy implementation becomes complicated. In addition to the number of policy actors involved, different comprehensions toward policy implementation also contributed to its complexity.

As stated in Regional Regulation Number 4 of 2007, considerations in the establishment of Malinau regency as conservation regency are:

(a) The living natural resources in Malinau regency which hold important meanings and roles to the life of living creatures, thus they need to be managed and utilized in harmony and in a balanced manner with the welfare of the local people while also preserving its sustainability;

(b) $90 \%$ of Malinau regency is covered by forest with various uses, thus conservation measures are needed to ensure that living natural resources and their ecosystems are preserved and the utilization is wisely managed so they can be in line with sustainable development; and

(c) Elements of living natural resources and their ecosystem are interdependent and influence each other, thus the damage an extinction of one element will affect the environment as a whole.

\section{METHODS OF RESEARCH}

Rather than the quantitative measures of the effect of regulation on local people, this research dominantly focused on the implementation process of Regional Regulation Number 4 of 2007 concerning Malinau Regency as Conservation Regency. Furthermore, this research includes the roles of actors involved, hindering and supporting factors, as well as the depiction of empirical model related to policy implementation process. Therefore, the researcher option for qualitative method than quantitative method as the research method. In details, the reasons qualitative method was used in this research:

- This research examine in depth and thoroughly (holistic approach) the conservation phenomenon in Malinau regency. In addition to the implementation process, it also examines the actors or stakeholders roles in implementing the policy contents as well as the hindering and supporting factors of the process;

- The majority of collected information is descriptive qualitative information that sourced from detail observation and in-depth interview, while there were not any questionnaires distributed to sample selected from a population;

- Instead of Malinau regency as a whole, this research is limited to the conservation area. Therefore, the proper approach is a case study approach.

There are also three reasons why researcher opted for case study approach, those reasons are:

- In order for the results of the research to provide important information about the inter-reality relationships which have been observed and the processes that occur in the implementation of conservation programs;

- The case study approach opens the opportunity for researcher to gain deep insights on actors roles within the process of implementation of the conservation programs, thus researcher can find the connection between roles of each actors within the process; 
- Through case study approach, based on analysis of existing model of the researched case, researcher can create recommendation model of ideal implementation of conservation policy that support sustainable and applicable forest development.

\section{RESULTS AND DISCUSSION}

Policy content discussed in this research is the basis of policy related to the implementation of policy concerning Malinau regency as conservation regency, thus it discusses the content of Regional Regulation Number 4 of 2007 that regulates all issues related to the implementation of conservation policy. The issues discussed include rights, obligations, and roles of actors; rights to conservation implementation; protection of conservation function; conservation area; sources of funds; structuring of conservation implementation; supervision and control; criminal provisions and investigation; regulation concerning the establishment of Malinau regency as a conservation policy is accepted by Malinau regency due to several reasons.

First of all, in regards to geographical location, Malinau regency is an area that ecologically serves as water system controller for the downstream area. Considering that water balance is influenced by forest preservation, forest destruction in the upstream does not only affect Malinau regency but also other regions in Borneo Island. In short, the future is heavily influenced by forest preservation in Malinau regency.

Secondly, due to the extensive of protected forest that include $56.51 \%$ of the total area, the duties and responsibilities are felt to be quite heavy. Central government, specifically The Ministry of Forestry, principally shoulders the responsibilities of safeguarding protected areas, including national park and protected forest. In reality, the regional officers do not able to optimally perform their duties due to lack of personnel, equipment, and funds. Of all existing protected areas, only the national park has a management unit based on Malinau equipped with proper facilities. Meanwhile, the other regionals are still directly managed by BKSDA, which based on Malinau.

Thirdly, the existing forest area is a massive factory that process flue gas, especially carbon dioxide, into oxygen that is essential for every living creatures in the world. Therefore, in general, Kalimantan alongside its vast forest area is often dubbed as "the lungs of the world" because vegetation are believed to be able to absorb carbon dioxide. Rapid industry development in the entire world resulted in an increase of flue gas that is the major contributor to the greenhouse effect, thus forests role to convert flue gas into oxygen is irreplaceable. Through Kyoto Protocol, which has not yet being ratified by Indonesian government, developed countries, which are members of Annex 1 of the Kyoto Protocol, are required to invest a part of their profits to save the forests. Meanwhile, target of investment countries are those developing countries that still have sizable area of forest. The last reason for the acceptance of conservation policy by Malinau regency government is because of the broader authority granted to the regional government.

Finally, law Number 22 of 1999 and Law Number 32 of 2014 bestow huge responsibilities to protect the forests and environment to regional governments. The authority granted covers all government affairs except defense and security, foreign relations, monetary, judicial, and religious affairs. This often affect the resource of regional government since, as the consequence of granted authority, the government are required to generate own-source revenue from the development of owned resources available to each regionals. Utilization of natural resources will, directly or indirectly, have an impact on environmental changes. Furthermore, exploitation activities such as utilization of forest products, forest conversion for other purposes, and minerals mining, will results in the loss of a number of habitats as well as reduced forest ability to convert flue gas into oxygen. In addition, these activities could cause a performance decline in the forest function as a rainwater catchment area, thus increase the frequency of flooding.

The research findings related to the contents of the policy are in line with Grindle (1980) theory of "Content and Context" which stated that the success of policy implementation is determined by contents. 
Contents of policy includes:

- Interest affected. A policy in its implementation involves many interests that influences the implementation process;

- Type of benefits. Policy contents are required to show and explain some type of benefits that have positive impacts which generated by the implementation of a policy;

- Extent of change envisioned. The policy is required to state the degree of change to be achieved;

- Site of decision-making. The location of decision making in a particular policy plays an important role in policy implementation phase. Thus, it is required to explain the location of decision-making. Furthermore, it is also required to assess whether the decision maker related to the policy implementation is appropriate.

- Program implementer. The success of policy or program execution depends on the existence of competent policy implementers involved, and has to be stated clearly in the policy contents that includes the duties and functions of each implementers.

- Resources committed. In regards to the utilized resources, a program, such as conservation program, has to be supported by adequate resources to ensure the success of implementation process.

Meanwhile, contexts of policy includes:

- Power, interest, and strategies of actors involved. It is necessary to consider the power, interests, and strategies used by actors involved in a policy to ensure the smooth running of a policy implementation. Without this consideration, it is possible that the results of implementation policy will differ from the expected results;

- Institution and regime characteristics. The environment in which a policy is implemented also influences its success. In regards to this context, local people who lives around the forest are required to be empowered in order for them to be able to support implemented conservation programs and activities;

- Compliance and responsiveness. In the process of implementing a policy, compliance and responsiveness from the implementers are crucial. This context is not only limited to regional governments and central government, but also includes donor countries, non-governmental organization, and other agencies that concerned about the protection and preservation of forest area.

The policy implementation process cannot be separated from policy contents, it becomes the foundation used in implementing the policy instead.

Ripley (1985), look at the policy implementation from two perspectives. The first perspective is a compliance perspective that means that the success of implementation is related to the compliance of the implementer in implementing different policies. Therefore, two major focuses of implementation studies which are compliance and "what is happening?" must be included in policy documents. The compliance aspect of policy implementers in complying with the standard operating procedures assessed using several indicators. Those indicators are:

- Do implementers comply with established procedures?

- Is the implementation of activities in accordance with the schedule that has been prepared?

- Are the target groups in accordance with the criteria set by the policy?

- Is the quality of policy output delivered to the target group in accordance to the standards set by the policy?

- Do implementers not violate the restrictions that have been made?

As for this research, the procedures for implementing policies and parties involved are regulated in Regional Regulation Number 4 of 2007, as well as the benefits that will be received by local people and the sanctions to violators of provisions contained in the policy content. 


\section{CONCLUSION AND RECOMMENDATIONS}

Policy implementation process influenced by four factors, those factors is policy contents, conservation area, human resources, and budget. Policy contents influence implementation because it is the groundwork of stakeholders involved in forest conservation activities. Policy contents have not clearly set sanctions for policy violators and the limits of policy implementer authority. Meanwhile, conservation area been regulated by the policy that includes national parks, protected forests and other conservation areas, such as forest area that are preserved and managed by local people, which are established by regent's decree based on applicable legislation. However, vague boundaries and lack of socialization of the conservation policy contents have led to violations of conservation forest boundaries by local people and industrialists. Furthermore, human resources related to Malinau regency policy as a conservation policy consist of government and non-government bodies such as Environment Agency of Malinau, Department of Forestry, Kayan Mentarang National Park, World Wildlife Fund, and youth activists. Readiness and availability related to human resource capacity have not met the required technical qualifications that include forest resource management, mapping, analysis, monitoring and evaluation of carbon deposits, and other technical capabilities. In addition, the ability to properly and precisely formulate policies is also lacking. Based on analysis and discussion on budget aspect, it can be concluded that normative funding has been regulated in the Regional Regulation of Malinau Regency Number 4 of 2007. It states that the sources of funding for conservation regency are from binding and non-binding sources. Binding sources includes the State Budget, Regional Development Budget I, Regional Development Budget II, and Special Fund for Conservation Regency. While non-binding sources includes funding from external funds, donor agencies, community, individual, private sector, carbon trading, and other environmental services. Presently, funding source for conservation is unlikely to come from regional development budget, thus funds from state budget and other non-binding resources are required. The existence of conservation policy helps protect the preservation of forest and the ecosystem, therefore is a wise decision taken by Malinau regency government to safeguard forest so that it could provide social and economical benefits to the people.

The roles of local governments in the process of implementing regional regulation concerning Malinau regency as a conservation regency includes execution of conservation program, protection of the conservation function, and structuring the implementation of conservation programs. The implementation of Regional Regulation Number 4 of 2007 concerning The Establishment of Malinau Regency as a Conservation Regency, especially supervision and controlling function, has been successfully executed by the appointed department. Department of Forestry has played a role to the conservation policy implementation in Malinau regency by conducting supervision to prevent damage on natural resources in conservation area. In addition, Department of Forestry has collaborated with village officials and local people who live around the conservation area to improve supervision effectiveness. Furthermore, Department of Forestry and village apparatus have optimally facilitated solving problems related to forest destruction. This can be seen from community activities to reforest deforested land by planting trees that are facilitated by Department of Forestry through distribution of tree seedlings using office's budget. The roles of local people and NGOs in the implementation of conservation policy have been stated in Regional Regulation Number 4 of 2007 wherein listed the rights, responsibilities, and roles of the local people. The locals have the same and widest opportunity to contribute in conservation efforts. The execution is carried out by improving the local people independence, local people empowerment, increased partnerships, developing local people abilities, fostering local people responsiveness to conduct supervision, feedbacks, as well as sharing information and report. Regional government has also collaborate with NGOs. Recently, regional government and World Wildlife Fund that based in Indonesia have collaborated to improve management capacity of Kayan Mentarang National Park through cooperation agreements that have significance nationally, as the groundwork for realizing a sustainable development model. Sustainable forest utilization is the ideal concept that must 
be achieved, thus World Wildlife Fund committed to help Malinau regency government to realize the ideal conservation regency as a form of sustainable development as well as calling all stakeholders to support Malinau regency during the implementation process. Meanwhile, private sectors have been exploiting the natural resources in conservation area without having a clear concept towards preservation of conservation area that led to forest destruction. Regional government often knows private sectors exploitations of natural resources without permissions from central government. However, misunderstanding on the regulation concerning forest management by private sector are due to vague authority ownership. To date, regional government assumed that the provincial government is the one responsible for the management. In fact, based on regulation, regional government is responsible to protected forest, while conservation forest and production forest are the responsibility of central government. Empirically, private sector's role in the form of corporate social responsibility funds is currently known to be minimal. Private sector's role through collaboration with government is not only limited to economic functions in the management of conservation area, it also has to pay attention to the ecological and social functions. The notion of conservation area privatization should also includes ensuring the functions and benefits of the region to remain in good condition, providing welfare for the local people, providing economic value to improve the quality of conservation area, and contribute donation for area development. All this time, Kayan Mentarang National Park considered containing many benefits that has not fully recognized and utilized. It is a conservation area that hold an important role in protecting the existence of ecosystems and their biodiversity while also as a representation of a particular ecotype.

The impact of implementation of Regional Regulation Number 4 of 2007 concerning Malinau Regency as a Conservation Regency occurs in primary forests, secondary forests, plantation forests, and protected forests. Furthermore, there is significant impact on socioeconomic of local people due to reduced unemployment through more job opportunities related to management of conservation forests. While the negative effect is conflicts that arised between local people and party responsible for forest management. The conflict generally related to the utilization of land, timber theft, and territorial boundaries that may be used by indigenous people. Furthermore, since the area to be utilized is narrow, locals are often utilizing land in protected forest illegally.

Factors that hinder the implementation include policy contents, policy environment, and social, economic and cultural. The failure of policy implementation is due to vague policy contents, which in turn caused by the purpose and objectives not clearly stated, facilities and prioritization as well as policy programs are too general while some are not stated. Furthermore, lack of supporting resources such as human, funds and time also contribute to the failure. Environmental factors also able to influences the policy, thus supervision is required to anticipate and improve readiness to overcome environmental problems that arises in the future. However, environmental becomes the hindering factor due to lack of supervision and control on the execution of planned activities. Economic barriers are created due to lack of funding to run the conservation program. Meanwhile, from the social aspect, lack of public knowledge about the importance of conservation for the protection of forest due to lack of socialization regarding conservation policy.

To be considered as ideal, conservation policy model must take into account the conservation area and the local people. The biodiversity in the conservation area has to be preserved while also fulfill the social and economic needs of the people living around the protected forest and conservation areas. These two conditions have to be maintained simultaneously in order for the conservation policy implementation to meet the objectives stated in Regional Regulation Number 4 of 2007 concerning Malinau Regency as a Conservation Regency.

Based on the conclusion, suggestions for improvement are as follows:

- Every policy making related to the utilization of forest resources has to involve local people since they are the first stakeholders to be impacted by the policy implementation. In addition, local people involvement will encouraged them to support the conservation policy achieving its objectives; 
- The wisdom of the local people must be considered in every policy making regarding the management of natural resources specifically that relates to their rights as Dayak tribe that has incorporated forest, land, and water to the characteristic of its culture and traditions;

- In realizing conservation regency, the implementation must be accompanied by programs that are designed to improve the welfare of local people, especially those who are partners of the government. Therefore, improvement of human resources must be prioritized;

- The participation of local people in achieving conservation objectives is the priority, thus it is hoped that the local people are willing to become government partner in achieving the objectives;

- As a region that has high degree of biodiversity, the role of higher education institutions, especially those based on East Kalimantan and North Kalimantan, are expected to further develop themselves in the field of research by increasing the number of researches especially those related to the welfare of local people since those who lives around the forest are classified as poor people.

\section{REFERENCES}

1. Departemen Kehutanan RI. 1990. UU No. 5 Tahun 1990 Tentang Konservasi Sumber Daya Alam Hayati dan Ekosistemnya [Law Number 5 of 1990 concerning Conservation of Living Resources and Their Ecosystems]. Jakarta: Dephut RI.

2. Edward III., G.C., 1980. Implementing Public Policy. Washington D.C: Congressional Quartely `Press.

3. Grindle, M.S., 1980. Politics and Policy Implementation in the Third World. New Jersey, Princenton: Princenton University Press.

4. Nugroho, Riant D., 2014. Kebijakan Publik: Formulasi, Implementasi dan Evaluasi. Jakarta: Elex Media Komputindo.

5. Pemerintah Indonesia. 2013. Undang-Undang Nomor 18 Tahun 2013 Tentang Pencegahan dan Pemberantasan Perusakan Hutan [Law Number 18 of 2013 concerning The Prevention and Eradication of Forest Destruction]. Jakarta: Sekretariat Negara

6. Pemerintah Indonesia. 1999. Undang-Undang Nomor 22 Tahun 1999 Tentang Pemerintahan Daerah [Law Number 22 of 1999 concerning Regional Administrations]. Jakarta: Sekretariat Negara

7. Pemerintah Indonesia. 2014. Undang-Undang Nomor 32 Tahun 2004 Tentang Pemerintahan Daerah [Law Number 32 of 2004 concerning Regional Administration]. Jakarta: Sekretariat Negara

8. Pemerintah Kabupaten Malinau. 2007. Peraturan Daerah Kabupaten Malinau Nomor 4 Tahun 2007 Tentang Kabupaten Malinau Sebagai Kabupaten Konservasi [Regional Regulation of Malinau Regency Number 4 of 2007 concerning Malinau Regency as a Conservation Regency]. Malinau: Pemerintah Kabupaten Malinau. 